\title{
REFLECTIONS
}

\section{Making Time to Write?}

Lucy M. Candib, MD

Department of Family Medicine and Community Health, University of Massachusetts Medical School, and Family Health Center of Worcester, Worcester, Mass
Conflicts of interest: none reported

\section{CORRESPONDING AUTHOR}

Lucy M. Candib, MD

Department of Family Medicine

and Community Health

University of Massachusetts Medical School and Family Health Center of Worcester 26 Queen St.

Worcester, MA 01610

lcandib@massmed.org

\begin{abstract}
Clinicians are busy people who must develop strategies for making time to write. With many obligations, their first strategy may be to try to clear the decks to make way for the current project. When writing takes on a more constant challenge, medical writers find themselves wedging writing in between myriad other tasks and commitments. Ultimately, committed writers, with effort and help, find a way to schedule writing as another essential activity in their lives.
\end{abstract}

Ann Fam Med 2005;3:365-366. DOI: 10.1370/afm.no.

$\mathrm{P}$ eople do not, of course, make time. Time exists, for practical purposes, as a linear flow, and people are swept along in it. Like a fast-moving river, time propels us forward, but sometimes we can swim hard to stay at the edges where the flow is a bit slower. So how do busy people find a way to write as they are swept along? I mean, how do people who are practicing clinicians-doctors, nurses, therapists-people with clinical commitments and sometimes life-and-death interruptions-how do they write?

The first strategy is the one that everyone hopes for, the open space, the dreamed opportunity that happens when you clear the decks. Having finished or set aside all other projects, you barricade yourself against interruptions, and work without pause for a heavenly period. How long this period is probably distinguishes your station in life, but it could be an hour, a morning, a weekend, a month, a summer-depending on one's position. The trouble with this strategy is that it means you can never do it until the decks are cleared, which means that it can be impossible to get to. Procrastination is the enemy of deck clearing. On the other hand, if deck clearing actually means going away to do it, then time for writing can be harder to arrange but less likely to suffer the interruptions of telephone, beeper, office, and so on. You are, after all, away. Going away, itself, requires deck clearing, so this whole strategy can be problematic if you are trying to defeat yourself.

Deadlines are the crutch for deck clearers. Once writing must get done, it moves to the top of the pile and loses its dreamlike quality of being optional ${ }_{i}$ it becomes obligation. Deck clearers are responsible people who fulfill their obligations. They write because they say they would and accomplish much through their relationships with those with and for whom they write. Deck clearers penalize themselves with guilt when they are unable to deliver on their promises, sometimes finally completing projects mostly to avoid the intolerable feeling of guilt. Deck clearing seems to be the strategy of those who see themselves, not as writers, but as doctors, nurses, therapists, or other clinicians who sometimes have to write something. Deck clearers respond to the deadlines of writing groups, classes, grants, chapters, and editors; they blossom when they incorporate writing into their identity. Timed free-writing exercises ${ }^{1}$ liberate deck clearers and teach them that all spaces are useful.

A second strategy is what I call "wedging it in." Those who wedge it in are driven to write and do it in between everything else. They don't have any choice. They earn their living as doctors, nurses, and so on, but they live to write. Medicine is their grist but milling is their work. William Car- 
los Williams, who saw himself as a writer first and had filled many notebooks before ever going to dental then medical school, pulled out a typewriter in the office between patients or wrote on the backs of envelopes in the car between house calls (sometimes). ${ }^{2}$ People wedge it in because they have to. Wedging gets writing done. Wedging provides drafts. Wedging uses the energy of the moment - the stuff that comes welling up, the adjective, phrase, allusion that must be captured. Wedgers use notebooks and carry them around all the time. I suspect poets of being wedgers at least some of the time. Others wedge prose into short intervals: 15 minutes between meetings; a half-hour between when the kids leave and they have to leave for work; an hour on the plane before the pilot's announcement to shut off electronic devices. Perri Klass describes wedging: "I stay up late when there's something due, I go off by myself on a weekend afternoon, I write on airplanes, or I just plain sit in my office when I ought to be doing something else, and steal a little time." (Perri Klass, personal communication, October 6, 2004). Wedgers are economical people who hate waste. Wedgers tend to be good schedulers; at some point they begin to use overlapping strategies to clear the decks and set aside time to work on all the bits and pieces they have piled up during wedging. Ultimately, wedgers set up regular times to write because they wither inside if they don't write.

Schedulers make up the third group. Sooner or later, most writers, after trying all sorts of strategies, become schedulers, but how they get there is variable. Some find themselves deck clearing so consistently that they turn into de facto schedulers. Exciting projects can catapult a deck clearer or a wedger into becoming a scheduler out of sheer enthusiasm. Some get tired of deadlines. They are dissatisfied with the limits of wedging. They have too much fun writing to leave it in the cracks. They (and their families) realize that their writing is so important that they come to agreements on how the time fits into their lives. (Wives help here. Flossie, William Carlos Williams' wife, took care of the children at night; wives deal with the social obligations. ${ }^{3}$ Women do better as writers when husbands become "wives.")

Some schedulers get up early in the morning, some write after others go to bed at night, some come home from work and write for a few hours with their work spread out on the dining room table. Gayle Stephens succeeded this way because EJ, mother of their 7 children, accepted this strategy. ${ }^{4}$ On the other hand, Joan Bolker, a writing therapist, says she has never known a woman who could do it at the dining room table. ${ }^{5}$ David Loxtercamp gets up at 4:30 AM, feeds the cats, and then starts to write. ${ }^{6}$ Richard Seltzer goes to bed at 8:30 PM, wakes up at $1 \mathrm{AM}$, writes for 2 hours, and then goes back to bed till $6 \mathrm{AM}^{7}$ Schedulers also create special space-a study, an alcove, a spot, a chair. Chekhov wrote on weekends in a cabin at the end of the cherry orchard behind the house. ${ }^{8}$ (He is famous for having said that medicine was his lawful wife, literature his mistress. When he was bored—also translated as "fed up" — with one, he would "spend the night" with the other. ${ }^{9}$ Today's women clinician writers, struggling for balance in their lives, may not see Chekhov's metaphor of a lover as useful; they may be spread between too many loves already.)

Schedulers have arrived at a time in their lives and their relationships where the questions of "if" (that plague the deck clearers), and "when" (that constrain the wedgers) get resolved into the "how" of accomplishment. Schedulers force themselves to confront their own motivation and to face off against the demons of self-doubt and procrastination. With time, clinicians who write will use various strategies, or combinations of strategies, to build writing into their lives. I confess, I am a deck clearer who romanticizes wedgers but longs to be a built-in scheduler. Schedulers ultimately find a way to invite the insistent mistress of writing into their work and family

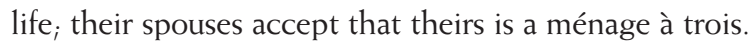

For myself, I still need to clear the decks and make an open space to write, but now I set aside a time to do it. This piece is a product of my Tuesday morning scheduled writing time.

To read or post commentaries in response to this article, see it online at http://www.annfammed.org/cgi/content/full/3/4/365.

Key words: Writing; journalism, medical; publications; authors

Submitted December 7, 2004; submitted, revised, January 30, 2005; accepted February 18, 2005.

Acknowledgments: Rosemary Leary and Andy Dzaugis of the Homer Gage Medical Library at UMass Memorial Medical Center provided essential research support. The Teacherless Writing Group of the Department of Family Medicine and Community Health provided helpful commentary on various drafts.

\section{References}

1. Elbow P. Writing with Power: Techniques for Mastering the Writing Process. New York, NY: Oxford University Press; 1981.

2. Williams WC. The Autobiography of William Carlos Williams. New York, NY: Random House; 1951.

3. Williams WC. William Carlos Williams. Writers at Work: The Paris Review Interviews. Third Series. New York, NY: The Viking Press; 1967.

4. Stephens GG. The Intellectual Basis of Family Practice. Tucson, Ariz: Winter Publishing; 1982.

5. Bolker J. A room of one's own is not enough. In: Bolker J, ed. The Writer's Home Companion. New York, NY: Henry Holt and Company; 1997:183-199.

6. Loxtercamp D. A Measure of My Days: The Journal of a Country Doctor. Hanover, NH: University Press of New England; 1997.

7. Selzer R. The pen and the scalpel. New York Times Magazine. August 21, 1988, 30-31.

8. Callow P. Chekhov: The Hidden Ground. Chicago, III: Ivan R. Dee; 1998.

9. Schwartz RS. "Medicine Is My Lawful Wife" -- Anton Chekhov, 18601904. N Engl J Med. 2004;351:213-214. 